\title{
Molecular characterization of an autolytic amidase of Listeria monocytogenes EGD
}

\author{
Anna M. McLaughlan and Simon J. Foster
}

Department of Molecular Biology and

Biotechnology, University of Sheffield, Firth Court, Western Bank, Sheffield S10 2TN, UK Author for correspondence: Simon J. Foster. Tel: +44 1142224411. Fax: + 441142728697.
e-mail: s.foster@sheffield.ac.uk

\begin{abstract}
The gene encoding a $102 \mathrm{kDa}$ autolysin has been cloned from an expression library of Listeria monocytogenes EGD genomic DNA, using a direct screening protocol. The encoded protein has two domains, an $\mathbf{N}$-terminal enzymic domain showing a high level of homology to the amidase domain of the major autolysin (at/) of Staphylococcus aureus, and a C-terminal, putative cell-wallbinding domain containing four imperfect direct repeats. In order to examine the role of the enzyme, the autolysin-encoding gene was insertionally inactivated by site-specific integration of a temperature sensitive plasmid. The enzyme accounts for $66 \%$ of the total lytic enzyme activity when $L$. monocytogenes walls are used as substrate and several of the major autolytic bands are missing on renaturing gels when compared to the wild-type. The enzyme does not appear to be directly involved in cell separation but has a role in motility. Characterization of the recombinant enzyme expressed in Escherichia coli has revealed it to be an amidase and to be able to hydrolyse a range of peptidoglycan substrates.
\end{abstract}

Keywords: Listeria monocytogenes, peptidoglycan hydrolase, autolysin, amidase

\section{INTRODUCTION}

Bacterial peptidoglycan hydrolases are ubiquitous amongst both Gram-positive and Gram-negative bacteria. Those that are capable of hydrolysing covalent bonds in the peptidoglycan of their own cell walls are referred to as autolysins (Ghuysen et al., 1966). It has been proposed that these enzymes play roles in a variety of important biological functions, including expansion of the cell wall, cell wall turnover during growth, splitting of the septum allowing cell division, motility, differentiation, and antibiotic-induced lysis (Ward \& Williamson, 1984). The fact that autolysins may also play a role as virulence factors has been one of much speculation although there is now direct evidence that these enzymes do contribute to pathogenesis (Berry et al., 1992, Mani et al., 1994).

The development of renaturing SDS-PAGE, and the construction of mutants inactivated in specific autolysin structural genes has allowed the autolytic complement of several bacteria to be elucidated. Multiple peptido-

Abbreviations: FDNB, 2,4-dinitrofluorobenzene; PITC, phenyl isothiocyanate

The GenBank accession numbers for the sequences reported in this paper are AF042193 and AF035424. glycan hydrolases from Bacillus subtilis have been identified and several studied at the molecular level (Smith et al., 1996). Renaturing gels of Staphylococcus aureus have revealed the presence of at least 20 lytic bands, although $>97 \%$ of this profile is due to the processed forms of the major bifunctional autolysin, Atl (Foster, 1995; Oshida et al., 1995). Relatively few studies have focused on the peptidoglycan hydrolases from Gram-negative bacteria apart from those in Escherichia coli (Höltje, 1995). However, the major autolysin from Pseudomonas aeruginosa has been characterized ( $\mathrm{Li}$ et al., 1996).

Listeria monocytogenes is a Gram-positive opportunistic pathogen that is environmentally widespread and causes severe food-borne infections in humans and animals (Farber \& Peterkin, 1991). We have previously characterized the peptidoglycan hydrolase profile of $L$. monocytogenes EGD under a variety of different environmental and physiological conditions (McLaughlan \& Foster, 1997). This revealed multiple bands of activity, which may represent many gene products or proteolytic processing of proforms, as seen in $S$. aureus (Foster, 1995). To determine the true number of autolysins that contribute to this profile, it is necessary to isolate structural genes and to create specific mutants. One extracellular protein called $\mathrm{p} 60$, produced by all 
virulent strains, has been identified and shown to have autolytic properties (Wuenscher et al., 1993). Mutants with reduced p60 levels are filamentous; the cells fail to separate after cell division and as a result, show reduced ability to invade host cells. Addition of p60 to these mutants disaggregates chains and at least partially restores invasiveness of the resulting single cells, implying a role for p60 in virulence (Kuhn $\&$ Goebel, 1989).

To further understand the roles of autolysins in the physiology of $L$. monocytogenes, we have used a direct screening method for the isolation of lytic-enzymeencoding genes. This has allowed the identification of a major autolysin encoding gene. The gene has been characterized and the function of the protein examined.

\section{METHODS}

Bacterial strains, plasmids and growth conditions. Bacterial strains and plasmids used in this study are shown in Table 1. L. monocytogenes strains were grown in Brain Heart Infusion broth (BHI; Oxoid) at $37^{\circ} \mathrm{C}$ with constant shaking (250 r.p.m.) unless otherwise stated, or on BHI plates $(1 \%$, $\mathrm{w} / \mathrm{v}$ agar). Escherichia coli XLOLR and XL-1 Blue MRF' were grown in Luria-Bertani broth (LB) or on LB agar [1\% (w/v)] at $37^{\circ} \mathrm{C}$.

Preparation of purified cell wall substrate. Purified cell wall preparations were prepared as previously described (Foster, 1992; McLaughlan \& Foster, 1997). Procion-Red-labelled walls of L. monocytogenes, Staphylococcus aureus, Micrococcus luteus and Bacillus subtilis were prepared as described previously (Foster, 1991).

Identification of lytic enzyme structural genes. A $\lambda$ ZAP Express library of $2-10 \mathrm{~kb} \mathrm{~L}$. monocytogenes EGD chromosomal DNA, partially digested with Sau3A, was constructed according to the manufacturer's instructions (Stratagene), in Bam HI-cut and dephosphorylated vector. A total of $1.1 \times 10^{5}$ independent insert-containing clones were produced and the library amplified once. The library was screened for lyticenzyme-producing clones by the plate assay, described previously, using Procion-Red-labelled cell walls as the substrate (Foster, 1991). Lytic-enzyme-producing clones were identified by a zone of clearing in the red wall background and were picked and purified by further rounds of plate screening. Purified clones were treated to excise the phagemid (pBKCMV) containing the L. monocytogenes DNA inserts, according to the manufacturer's protocol (Stratagene), and clones were checked for recombinant lytic activity by the plate test (Foster, 1991). DNA was isolated from these clones and characterized by restriction analysis. All molecular biological methods were performed as in Sambrook et al. (1989).

Preparation of samples and renaturing SDSPAGE. Samples containing peptidoglycan hydrolases were prepared and analysed by renaturing gel electrophoresis as previously described (Foster, 1992); $11 \%$ (w/v) acrylamide gels containing $0.05 \%(\mathrm{w} / \mathrm{v})$ purified bacterial walls were utilized. Peptidoglycan hydrolase activity was detected as zones of clearing in the blue-stained cell wall background.

Molecular analysis of the lytic enzyme clones. Nested deletions were prepared using the Erase-A-Base system (Promega) and used for sequencing. DNA sequence was determined from both strands using the dideoxy method. Synthetic oligonucleotide fragments based on DNA sequence generated during this work, or to vector sequence, were used as primers. DNA sequence was edited and analysed using the Staden package. Putative open reading frames were examined using the NIP program and the deduced amino acid sequences were compared to the NCBI Entrez protein databases by BLAST searches.

Preparation of fractions containing recombinant enzyme. For biochemical analysis, 41 cultures of $E$. coli containing pAMB8 were grown in the presence of IPTG $(1 \mathrm{mM})$, to $\mathrm{OD}_{600} 1.5$ after inoculation with $0.01 \mathrm{vol}$. overnight culture. The cells were harvested by centrifugation $\left\langle 11000 \mathrm{~g}, 4^{\circ} \mathrm{C}\right.$, $10 \mathrm{~min}$ ) and broken in a French press $(180 \mathrm{MPa})$ in $40 \mathrm{ml}$ $50 \mathrm{mM}$ Tris/ $\mathrm{HCl}(\mathrm{pH} \mathrm{7.6}), 200 \mathrm{mM} \mathrm{NaCl}, 0.5 \mathrm{mM}$ PMSF at

Table 1. Strains and plasmids

\begin{tabular}{|c|c|c|}
\hline Strains or plasmids & Relevant genotype/phenotype & Source/reference \\
\hline \multicolumn{3}{|l|}{ Strains } \\
\hline L. monocytogenes EGD & Wild-type & Wuenscher et al. (1993) \\
\hline L. monocytogenes AM101 & ami::pAMB15; Ery ${ }^{\mathrm{r}}$ & This study \\
\hline E. coli XL-1 Blue & Tet $^{r}$ & Stratagene \\
\hline E. coli XLOLR & Tet $^{r}$ & Stratagene \\
\hline \multicolumn{3}{|l|}{ Plasmids } \\
\hline pBKCMV & $\operatorname{Kan}^{r}$ & Stratagene \\
\hline pAMB8 & $\begin{array}{l}\text { pBKCMV with } 3.2 \mathrm{~kb} \text { insert carrying } \\
\text { truncated } L . \text { monocytogenes ami } \\
\text { gene; } \operatorname{Kan}^{\mathrm{r}}\end{array}$ & This study \\
\hline pAMB9 & $\begin{array}{l}\text { pBKCMV with } 1.8 \mathrm{~kb} \text { insert carrying } \\
\text { L. monocytogenes phage A } 118 \text { lytic } \\
\text { enzyme gene; Kan }{ }^{\mathrm{r}}\end{array}$ & This study \\
\hline pAULA & Ery ${ }^{r}$ & Chakraborty et al. (1992) \\
\hline pAMB15 & $\begin{array}{l}\text { BamHI/EcoRI-cut pAULA with } \\
768 \text { bp BamHI/EcoRI internal ami } \\
\text { fragment; Ery }\end{array}$ & This study \\
\hline
\end{tabular}


$4{ }^{\circ} \mathrm{C}$. After removal of debris by centrifugation $(100000 \mathrm{~g}$, $4^{\circ} \mathrm{C}, 2 \mathrm{~h}$ ), the supernatant was dialysed overnight against 100 vols $20 \mathrm{mM}$ potassium phosphate buffer $(\mathrm{pH} 7 \cdot 4)$ at $4^{\circ} \mathrm{C}$. The dialysate was then centrifuged $\left(100000 \mathrm{~g}, 4^{\circ} \mathrm{C}, 2 \mathrm{~h}\right)$; the pellet was resuspended in $20 \mathrm{mM}$ Tris $/ \mathrm{HCl}(\mathrm{pH} 7 \cdot 6$ ), $200 \mathrm{mM}$ $\mathrm{NaCl}$, stored at $-20^{\circ} \mathrm{C}$ and used directly as the enzyme source.

Assay for autolytic activity. Lytic activity of the enzyme extract was determined spectrophotometrically by the ability of the extract to decrease the optical density of a cell wall suspension. Unless stated otherwise, the reaction contained $1 \mathrm{ml} 20 \mathrm{mM}$ Tris/ $\mathrm{HCl}(\mathrm{pH} 7 \cdot 6), 200 \mathrm{mM} \mathrm{NaCl}$ and purified cell walls to a final $\mathrm{OD}_{450}$ of $0 \cdot 25$. One unit (U) of enzyme activity is defined as the amount of enzyme necessary to decrease the $\mathrm{OD}_{450}$ of a wall suspension by $0.001 \mathrm{~min}^{-1}$ at $37^{\circ} \mathrm{C}$, measuring the maximum initial rate (Foster, 1991).

Determination of hydrolytic bond specificity. Purified cell walls of $B$. subtilis (1 mg dry weight) in $20 \mathrm{mM}$ Tris $/ \mathrm{HCl}$ ( $\mathrm{pH} 7.6), 200 \mathrm{mM} \mathrm{NaCl}$ in a total volume of $1 \mathrm{ml}$ were digested for $4 \mathrm{~h}$ at $37^{\circ} \mathrm{C}$ with $16.5 \mathrm{U}$ recombinant enzyme. Digestion of the walls was followed spectrophotometrically, the $\mathrm{OD}_{450}$ decreasing from 0.529 to 0.04 . The hydrolytic bond specificity of the autolysin was determined by analysing the $\mathrm{N}$ terminal amino acid ratios after digestion. The soluble digested walls were assayed for amino groups released by amidase activity by labelling with 2,4-dinitrofluorobenzene (FDNB). To $100 \mu \mathrm{l}$ of the digested walls, $150 \mu \mathrm{l} \mathrm{NaCO} \mathrm{N}_{3}(1 \%$, $\mathrm{w} / \mathrm{v}), 62.5 \mu \mathrm{l}$ borax $(5 \%, \mathrm{w} / \mathrm{v})$ and $31.5 \mu \mathrm{l}$ FDNB solution $(130 \mu \mathrm{l}$ in $10 \mathrm{ml} 100 \% \mathrm{v} / \mathrm{v}$ ethanol) were added, and the solution incubated at $60^{\circ} \mathrm{C}$ for $30 \mathrm{~min}$ (Margot et al., 1991). The reaction was stopped by adding $50 \mu 15 \mathrm{M} \mathrm{HCl}$ and the labelled samples were acid-hydrolysed for $14 \mathrm{~h}$ at $110^{\circ} \mathrm{C}$ under vacuum. The hydrolysates were then dried and derivatized with phenyl isothiocyanate (PITC) at $110^{\circ} \mathrm{C}$ (Atrih et al., 1996). The derivatives were analysed by HPLC and the amount of PITC-labelled alanine determined in both digested and control samples. The constant peptidoglycan-associated glutamic acid levels were used as an internal control.

Insertional inactivation of the autolysin-encoding gene. A $768 \mathrm{bp}$ internal fragment from the sequenced autolysin gene, cloned in PAMB8, was amplified by PCR and suitable restriction sites introduced at each end. The primers used were AM43 (5'-ATATGGATCCGTAGACGGTCAAGCTACTTATATCC-3'; BamHI restriction site underlined) and AM44 (5'-GCCGGAATTCGCCTGTTGCTGTTTTGACTCGGCTA-3'; EcoRI restriction site underlined). After EcoRI and BamHI digestion, the PCR product was cloned into dephosphorylated EcoRI- and BamHI-digested pAULA (Chakraborty et al.,1992), to give pAMB15. This plasmid was transformed by electroporation at $30^{\circ} \mathrm{C}$ (Park \& Stewart, 1990 ) into L. monocytogenes EGD; transformants were selected on BHI plates containing erythromycin $\left(1 \mu \mathrm{g} \mathrm{ml}^{-1}\right)$ at $30^{\circ} \mathrm{C}$. Transformants were grown in BHI broth containing $1 \mu \mathrm{g}$ erythromycin $\mathrm{ml}^{-1}$ at $30^{\circ} \mathrm{C}$ for $12 \mathrm{~h}$. The culture was diluted $1 / 100$ into fresh BHI containing erythromycin $(1 \mu \mathrm{g}$ $\mathrm{ml}^{-1}$ ) at $42^{\circ} \mathrm{C}$. After $18 \mathrm{~h}$ the culture was diluted as above and grown for a further $12 \mathrm{~h}$, prior to plating of putative mutants on erythromycin-containing $\mathrm{BHI}$ plates at $42^{\circ} \mathrm{C}$. The correct insertional event was confirmed by Southern blotting and probing with an internal fragment of the autolysin gene.

Swarm plate assay. Swarming motility was measured using BHI $0.3 \%(w / v)$ agar. Samples from overnight liquid cultures were spotted onto the centre of each plate and incubated overnight at $25^{\circ} \mathrm{C}, 30^{\circ} \mathrm{C}$ and $37^{\circ} \mathrm{C}$. Swarming motility was measured as a percentage of the wild-type diameter. The results are a mean of two repetitions.

Cell autolysis. Cultures of mutant and wild-type L. monocytogenes strains were grown to early exponential phase $\left(\mathrm{OD}_{600} 0.25\right)$ in BHI broth. For determining the effect of penicillin-induced lysis, $1.25 \mu \mathrm{g}$ penicillin $\mathrm{G} \mathrm{ml}^{-1}(10 \times \mathrm{MIC})$ was added, and the lysis of the cultures followed spectrophotometrically (Unicam SP1800 ultraviolet spectrophotometer, path length of cuvette $1 \mathrm{~cm}$ ) while continuing incubation at $37^{\circ} \mathrm{C}$ with shaking. For determining the effect of Triton X-100, the cells were grown to $\mathrm{OD}_{600} \sim 0.6$, harvested $(6000 \mathrm{~g}$, room temperature, $10 \mathrm{~min})$ and resuspended in $50 \mathrm{mM}$ Tris $/ \mathrm{HCl}(\mathrm{pH} \mathrm{7.6)}, 0.05 \%$ (v/v) Triton X-100. The lysis of the suspension at $37^{\circ} \mathrm{C}$ was followed spectrophotometrically. The results stated are from two independent experiments.

Lithium chloride extraction of whole cells. Extraction of whole cells with $4 \mathrm{M}$ lithium chloride, to release peptidoglycan hydrolases, was performed as described previously (Foster, 1992).

\section{RESULTS}

\section{Identification of lytic enzyme structural genes}

A $\lambda$ ZAP library of L. monocytogenes genomic DNA was screened for lytic-enzyme-producing clones by a direct screening protocol. Lytic enzyme clones are characterized by a zone of clearing in the red wall overlay around the plaque. After an initial screening of approximately $2 \times 10^{5}$ insert-containing clones, a total of 10 lytic-enzyme-producing clones were isolated using B. subtilis, and 19 using $M$. luteus Procion-Red-labelled walls as substrate. L. monocytogenes and S. aureus walls were also used but no expressing clones were isolated using these substrates. The putative phage clones were purified by rescreening prior to excision as phagemids.

The ability of $E$. coli to express the recombinant lytic enzymes was tested using Procion-Red-labelled wall overlay plates (Foster, 1991). All 10 of the clones initially isolated using $B$. subtilis walls retained activity when tested once again on $B$. subtilis walls, but interestingly, all of these clones except one (containing pAMB9) were also able to hydrolyse $M$. luteus cell walls. From the total of 19 clones isolated using $M$. luteus cell walls, two retained activity on the original substrate and only one of these was also capable of hydrolysing $B$. subtilis walls. The ability of the clones to hydrolyse the cell walls was not IPTG dependent. E. coli expressing $\mathrm{pBKCMV}$ (vector without insert) showed no activity on red-wall overlays.

Restriction analysis and Southern blotting revealed that two distinct lytic-enzyme-encoding genes had been isolated. One gene was represented by nine of the clones originally isolated by plating on $B$. subtilis and M. luteus walls. Of these clones, pAMB8 was used for sequencing and further characterization. This plasmid contained an insert of approximately $3.2 \mathrm{~kb}$. The other gene was represented by the remaining three clones isolated using B. subtilis walls; E. coli pAMB9 was chosen as a 


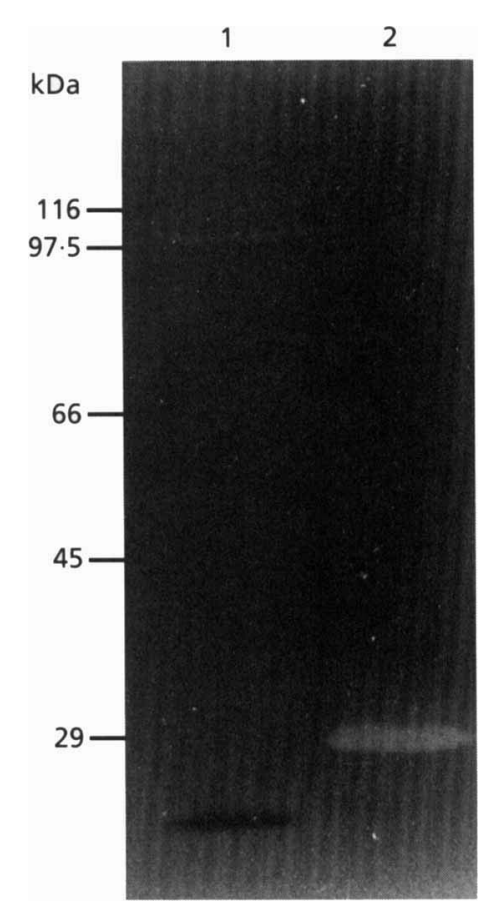

Fig. 1. Lytic activity of recombinant clones. Samples were prepared as described in Methods. Renaturing SDS-PAGE was performed using an $11 \%(w / v)$ acrylamide gel containing $0.05 \%(w / v) L$ L. monocytogenes cell walls. The positions of molecular mass standards separated on the same gel are indicated. Lane $1, E$. coli XLOLR(pAMB8) containing the equivalent of $100 \mu$ l original culture $\left(O D_{600} 1.0\right)$; lane $2, E$. coli XLOLR(PAMB9) containing the equivalent of $0.1 \mu \mathrm{l}$ original culture $\left(O D_{600} 1.0\right)$.

representative clone for sequencing (insert approximately $1.8 \mathrm{~kb}$ ).

\section{Renaturing gel analysis}

E. coli XLOLR strains expressing the recombinant enzymes were grown with and without IPTG $(1 \mathrm{mM})$. The cells were harvested at mid-exponential phase $\left(\mathrm{OD}_{600} 1 \cdot 0-1 \cdot 2\right)$ and SDS cell extracts prepared (Foster, 1992). Addition of IPTG did not affect the growth rate of the cells. The protein samples were analysed by renaturing SDS-PAGE (Fig. 1). A lytic band of $104 \mathrm{kDa}$ was seen in extracts from E. coli XLOLR(pAMB8) (lane 1) and a band of $33 \mathrm{kDa}$ was seen from E. coli XLOR(pAMB9) (lane 2). The E. coli XLOLR(pBKCMV) extract (plasmid without insert) showed no lytic enzyme activity (results not shown). The presence of IPTG in the growth medium had no effect on the bands seen on the gel.

\section{Sequencing of the lytic enzyme clones}

DNA sequence analysis of pAMB9 revealed the presence of a gene encoding a protein of 281 amino acids. This protein shows $96 \%$ identity over its entire length to the previously characterized lytic L-alanoyl-D-glutamate peptidase of L. monocytogenes phage A118 (Loessner $e t$ al., 1995). Upstream of the putative peptidase-encoding gene in pAMB9, most likely in the same operon, is a gene encoding a probable holin. This gene is truncated at its $5^{\prime}$ end in pAMB9, but the truncated protein encoded shows $100 \%$ identity (over 35 amino acids) with the holin of phage A118. Thus, the recombinant peptidoglycan hydrolase cloned on pAMB9 is likely to be of phage origin and may represent that of A118 or a very closely related phage. It is at present unknown whether the pAMB9-encoded peptidoglycan hydrolase is part of a phage inserted into the chromosome of L. monocytogenes.

The entire DNA sequence of the pAMB8 insert (3229 bp) was determined and two putative ORFs were identified (Fig. 2). The major ORF encodes a protein that is truncated at its $\mathrm{N}$-terminus in pAMB8. Despite repeated screening of the library, a clone containing the rest of the gene could not be isolated. Recently, the sequence of the gene has been reported and a similar problem was encountered (Braun et al., 1997). PCR was used to obtain the final $99 \mathrm{bp}$ of the sequence based on that published. Braun et al. (1997) have called the gene ami and this nomenclature has been retained. The complete gene encodes a protein of 917 amino acids with an estimated molecular mass of $102 \mathrm{kDa}$. The protein has two apparent domains (Fig. 2). The C-terminal domain shows four repeat regions, each between 145 and 160 residues long, which show $67 \cdot 1 \%$ identity between all four. The C-terminal amino acid sequence also shows homology to the C-terminal repeating region of InlB from L. monocytogenes ( $54 \%$ identity over 219 aa; Fig. 2 ). The N-terminal domain shows significant homology ( $49 \%$ identity in a 183 aa overlap) to the N-terminal amidase domain of Atl, the major autolysin of $S$. aureus (Fig. 2; Foster, 1995; Oshida et al., 1995).

ORF 2 is apparently transcribed convergently to ami and the encoded protein is N-terminally truncated by the end of the clone. ORF 2 shows homology $(67 \cdot 6 \%$ identity over $173 \mathrm{aa}$ ) to a CTP synthase from B. subtilis.

\section{Characterization of the recombinant lytic enzyme}

The N-terminally truncated Ami protein expressed from pAMB8 was partially purified by precipitation in a lowsalt buffer ( $20 \mathrm{mM}$ potassium phosphate). The single dialysis step increased the specific activity of the enzyme 30 -fold. The precipitated enzyme was only soluble at high salt concentrations $(200 \mathrm{mM} \mathrm{NaCl})$. Partial purification by selective precipitation of recombinant lytic enzymes has been previously noted (Foster, 1991). The enzyme was able to hydrolyse a variety of cell wall types including L. monocytogenes (Table 2), but showed the most activity on cell walls of $B$. subtilis. The enzyme had no activity on cell walls from $S$. aureus or on spore cortex from Bacillus megaterium. The optimum $\mathrm{pH}$ for the activity of the recombinant enzyme was $\mathrm{pH} 7.6$ in $20 \mathrm{mM}$ potassium phosphate buffer (results not shown). The presence of $\mathrm{K}^{+}(200 \mathrm{mM}), \mathrm{Li}^{+}(200 \mathrm{mM}), \mathrm{Hg}^{2+}$ $(1 \mathrm{mM}), \mathrm{Zn}^{2+}(2 \mathrm{mM})$ and $\mathrm{Ca}^{2+}(2 \mathrm{mM})$ all significantly 


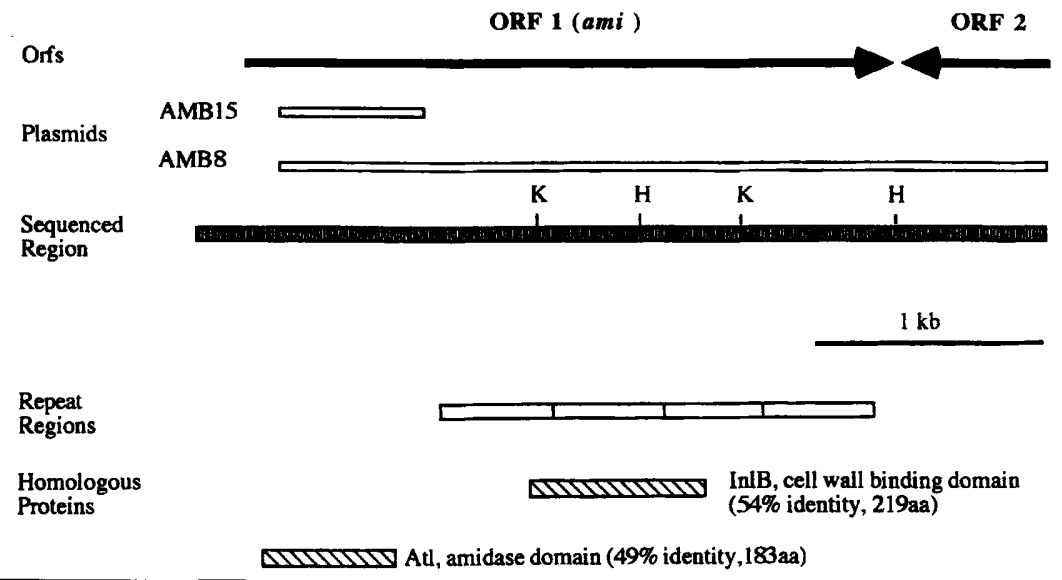

Fig. 2. Physical and genetic map of the autolysin gene region. The map shows the plasmids used for sequencing and inactivation. Restriction enzyme sites are marked ( $\mathrm{K}, \mathrm{Kpnl}$; $\mathrm{H}$, HindIII). The positions and orientations of the two ORFs and the positions of the direct repeats are indicated. The regions of homology to other proteins are shown as shaded boxes with the name of the homologous protein and, indicated in parentheses, the percentage identity and the length of the homologous region.

Table 2. Substrate specificity of recombinant enzyme

\begin{tabular}{|lc|}
\hline Substrate & $\begin{array}{c}\text { Activity } \\
(\%)^{*}\end{array}$ \\
\hline B. subtilis 168 vegetative cell walls & 100 \\
L. monocytogenes EGD cell walls & 73 \\
M. luteus 4698 ATCC cell walls & 38 \\
S. aureus 8325/4 cell walls & $<1$ \\
Bacillus megaterium KM spore cortex & $<1$ \\
Lactobacillus arabinosus NCIB 6376 cell walls & 38 \\
\hline
\end{tabular}

* Activity measured as a percentage of that using B. subtilis 168 vegetative walls $(100 \%, 16.5 \mathrm{U})$ in $20 \mathrm{mM}$ Tris $/ \mathrm{HCl}(\mathrm{pH} \mathrm{7.6)}$, $200 \mathrm{mM} \mathrm{NaCl}$ at $37^{\circ} \mathrm{C}$. An equivalent amount of E. coli XLOLR(pBKCMV) cell extract contained $<0 \cdot 1 \%$ of the control enzyme activity.

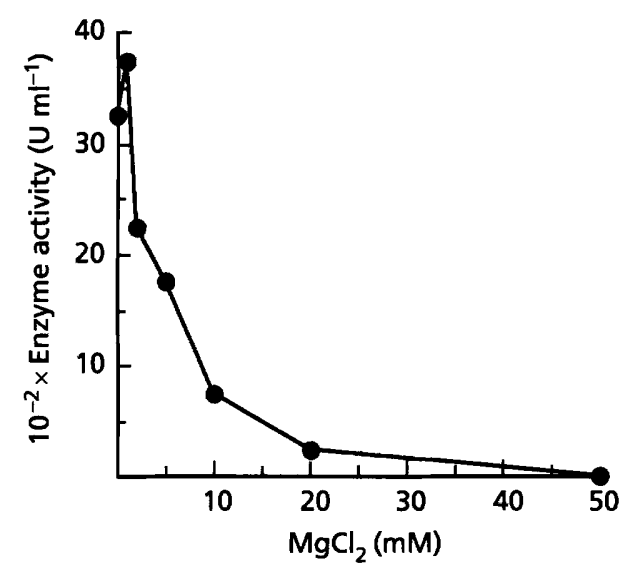

Fig. 3. Effect of $\mathrm{Mg}^{2+}$ on activity of the recombinant enzyme. Lytic activity of the enzyme extract was determined spectrophotometrically. The reaction contained $1 \mathrm{ml}$ cell walls in $20 \mathrm{mM}$ Tris $/ \mathrm{HCl}(\mathrm{pH} 7.6), 200 \mathrm{mM} \mathrm{NaCl}$ to a final $\mathrm{OD}_{450}$ of 0.25 and different concentrations of $\mathrm{MgCl}_{2}$.

inhibited activity (by $92 \%, 85 \%, 62 \%, 54 \%$ and $23 \%$ respectively). Activity was stimulated by low concentrations of $\mathrm{Mg}^{2+}$ (Fig. 3), with an apparent optimum of
$1 \mathrm{mM}$, and inhibited by the presence of $5 \mathrm{mM}$ EDTA (by $62 \%$ of control).

\section{Determination of hydrolytic bond specificity}

Sequence homology suggested that ami encoded an amidase. To determine the hydrolytic bond specificity of the recombinant enzyme, amino acids from digested $B$. subtilis cell walls were analysed. If Ami is an amidase then its activity would be expected to liberate free Lalanine amino groups, which could be labelled with FDNB. If the digested, FDNB-labelled material is subsequently acid hydrolysed, all the amino groups of the peptidoglycan-associated amino acids will be exposed, apart from those previously labelled with FDNB. The newly exposed free amino groups could then be labelled with PITC and quantified. If Ami is an amidase then it would be expected that the amount of PITClabelled alanine would decrease in the enzymically digested sample versus an untreated control, as a proportion would be present as a dinitrophenyl derivative (after the FDNB reaction) and so not available for PITC substitution. Thus, by comparison of the amount of PITC-labelled alanine in the peptidoglycan before and after Ami digestion, it is possible to determine whether Ami is likely to be an amidase. In the digested sample labelled with FDNB, there was a decrease of about $53 \%$ in the amount of free alanine $\mathrm{N}$-termini detectable by PITC labelling and HPLC analysis, compared to that from FDNB-labelled undigested walls. This decrease in the amount of free alanine shows that the Ami enzyme is likely to have amidase activity.

\section{Analysis of the role of Ami}

To determine the function of Ami, a mutant of $L$. monocytogenes EGD insertionally inactivated in the ami gene was constructed. An internal fragment of $768 \mathrm{bp}$ from the ami gene was amplified by PCR and cloned into pAULA in E. coli to create pAMB15. The plasmid was transformed into L. monocytogenes EGD and maintained at a permissive temperature $\left(30^{\circ} \mathrm{C}\right)$. The plasmid contains a temperature sensitive replicon and when the cells were successively subcultured at the non-permissive temperature $\left(42^{\circ} \mathrm{C}\right)$, the plasmid 
(a)

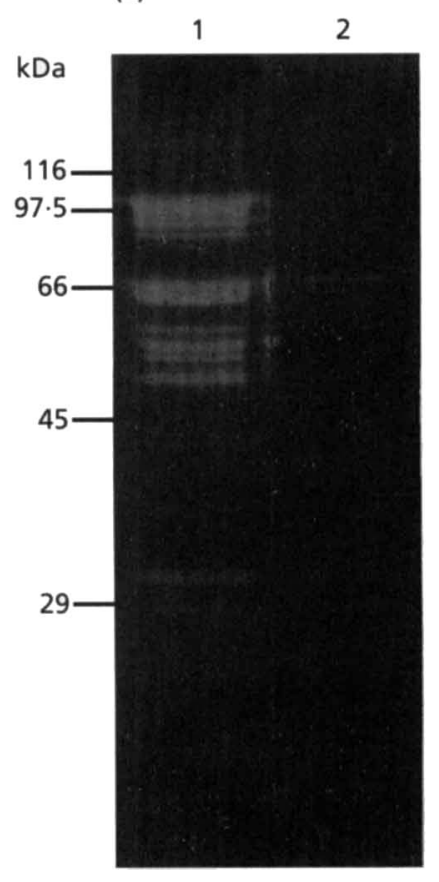

(b)

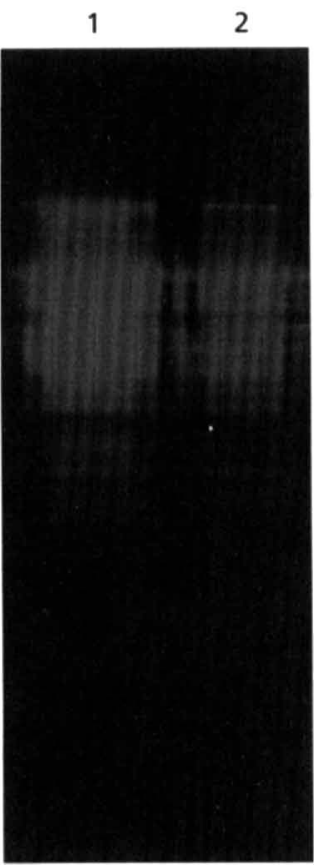

(c)

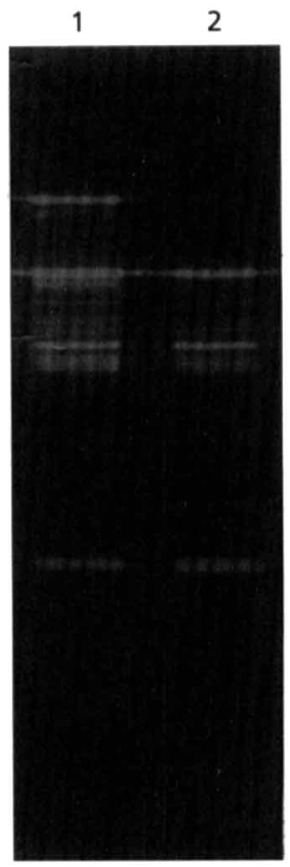

Fig. 4. Autolysin profiles of $L$ monocytogenes strains. Cultures were grown in $\mathrm{BHI}$ to $\mathrm{OD}_{600}$ of $1-1.5$ at $37^{\circ} \mathrm{C}$ prior to harvesting, SDS extraction, separation by SDS-PAGE and renaturation as described in Methods. Each lane contains the extract from the equivalent of $600 \mu \mathrm{l}$ of original culture $\left(O D_{600} 1.0\right)$. The positions of molecular mass standards separated on the same gels are indicated. The gels contained $0.05 \% \quad(w / v)$ cell walls from $L$. monocytogenes (a), M. luteus (b) or B. subtilis (c). Lanes: 1, EGD (wild-type); 2, AM101 (ami). recombined at the region of homology with the host chromosome, thus inactivating ami. After two rounds of enrichment, a number of putative ami mutants were selected and analysed by Southern blotting for the correct integrational event (results not shown). One of these mutants, AM101, was used for the analysis of the role of Ami in cellular physiology.

The autolysin profiles of EGD (wild-type) and AM101 (ami) were compared by renaturing SDS-PAGE, using various substrates (Fig. 4). Using L. monocytogenes walls as substrate, the wild-type showed multiple bands ranging from 33 to $104 \mathrm{kDa}$ (Fig. 4a, lane 1) as previously shown (McLaughlan \& Foster, 1997). In contrast, AM101 had reduced activity of most bands (Fig. 4a, lane 2), with only bands of 77 and $33 \mathrm{kDa}$ remaining prominent. Thus, most of the lytic bands present in the profile may be due to proteolytic processing of the $104 \mathrm{kDa}$ proform. However, when using $M$. luteus or $B$. subtilis walls as substrate, only the $104 \mathrm{kDa}$ band was markedly reduced, suggesting the presence of other enzymes with different substrate specificities. As Ami is produced by $L$. monocytogenes and can hydrolyse its own walls it can be called an autolysin.

The role of the ami gene was examined by a phenotypic comparison of AM101 (ami) and EGD (wild-type). No difference in the growth rate of the two strains was detected and the mutant did not appear to be impaired in cell division over a range of temperatures $(25,30,37$ and $42{ }^{\circ} \mathrm{C}$ ). Ultrastructural analysis by electron microscopy did not reveal any significant differences in the morphology of the cell wall.

The possible role of the autolysin in motility was analysed by growth on swarm plates, where motile strains can be seen forming a diffuse growth around the central colony. Both wild-type and mutant strains were non-motile at $37^{\circ} \mathrm{C}$. There was a slight decrease in the motility of the mutant compared to the wild-type at $30{ }^{\circ} \mathrm{C}$ ( $85 \%$ of wild-type diameter), at $25^{\circ} \mathrm{C}(67.5 \%$ of wild-type diameter) and at room temperature $(81 \%$ of wild-type diameter).

Penicillin-induced cell lysis was determined by the addition of penicillin $\mathrm{G}$ to growing cultures. After $24 \mathrm{~h}$ the treated EGD (wild-type) and AM101 (ami) cultures both had a final $\mathrm{OD}_{600}$ of $0 \cdot 2-0 \cdot 25$. Plate counts revealed that the bacteriocidal effect of the drug was unaltered in the mutant. From these results it appears that Ami does not have a role in penicillin-induced lysis. However, neither strain lysed completely. Similarly, Ami is not involved in Triton-X-100-induced lysis, as both the mutant and the wild-type lysed at the same rate (results not shown).

Lithium chloride extraction of total lytic enzyme activity from the cells revealed that AM101 (ami) had $34 \%$ and $83 \%$ of the parental (EGD) activity using L. monocytogenes or $M$. luteus walls respectively as the substrate, when assayed spectrophotometrically. There was no difference in the activity of the wild-type and the mutant when assayed using $B$. subtilis walls as substrate.

\section{DISCUSSION}

This paper describes the cloning and characterization of an autolytic amidase from $L$. monocytogenes EGD. During the preparation of this paper, the cloning and sequencing of the autolysin gene was published by Braun et al. (1997) and the gene designated ami. They identified the gene by the Southern blotting of $L$. monocytogenes EGD chromosomal DNA using the 3' end of the inlB gene as a probe. 
The ami gene encodes a protein of 917 amino acids with a deduced molecular mass of $102 \mathrm{kDa}$. This molecular mass is in reasonable agreement with the size $(104 \mathrm{kDa})$ of the lytic activity of the truncated recombinant protein observed on renaturing gels. The Ami protein is predicted to have a two-domain structure. The presence of two domains (a catalytic domain and a non-catalytic, cell-wall-binding domain) appears to be a common feature of autolysins (Chu et al., 1992; Kuroda et al., 1992; Romero et al., 1990). The high homology (49\% identity over $183 \mathrm{aa}$ ) of the N-terminal domain of Ami to the amidase domain of the $S$. aureus autolysin Atl (Foster, 1995, Oshida et al., 1995), suggests that Ami also has amidase activity. Using an HPLC-based method we have demonstrated the likely amidase activity of the enzyme.

The C-terminal domain of Ami contains four imperfect direct repeats, which are between 145 and 160 residues long and show $67.1 \%$ identity between the four. A characteristic series of repeat sequences in the noncatalytic domain of autolysins is thought to be necessary for specific cell wall binding. The LytA amidase of Streptococcus pneumoniae has a two-domain structure: an N-terminal catalytic domain and a C-terminal domain with six repeat regions. By a series of deletions, Garcia et al. (1994) showed that at least four of the repeat regions are necessary for the efficient recognition and attachment of the autolysin to choline residues in the pneumococcal cell wall. This suggests the necessity of enzyme attachment to the cell wall in order to maintain high catalytic efficiency. Similarly, when the catalytic domain of $\mathrm{CwlB}$ (the major vegetative-cell autolytic amidase) from $B$. subtilis was deleted, the enzyme retained the ability to bind to $B$. subtilis cell walls, suggesting that the repeating sequences found in the non-catalytic region may be essential for binding (Kuroda \& Sekiguchi, 1991). The autolysin CwlM from Bacillus licheniformis has an N-terminal catalytic domain and a C-terminal domain containing repeated sequences (Kuroda et al., 1992). CwlM normally showed more activity on $M$. luteus cell walls than B. subtilis or $B$. licheniformis as substrate, but in contrast, a mutant truncated at the $\mathrm{C}$ terminus had lost this preference, suggesting that the (non-catalytic) C-terminus is essential for substrate specificity (Kuroda et al., 1992).

The involvement of direct amino acid repeats in wall binding has also been postulated in a wall-associated protein (Wap) without autolytic activity. Processed forms of WapA constitute several of the major Waps of B. subtilis (Foster, 1993). WapA has two domains, an Nterminal domain containing three repeats (similar to those found in autolysins) and a C-terminal domain containing a different kind of repeat: 31 repeats of a motif in two areas (Foster, 1993). Deletion analysis showed that the N-terminal direct repeats were necessary for cell wall binding (Foster, 1993).

The C-terminal domain of Ami has homology (54\% identity over 219 aa) to the InlB surface-anchoring domain. InlB is a member of the internalin family, which have important roles in the pathogenicity of L. monocytogenes (Dramsi et al., 1995, 1997). The C-terminal domain of InlB may therefore be involved in cell wall binding.

The $5^{\prime}$-truncated ami gene can be stably maintained and expressed in E. coli. However, the whole gene could not be cloned, even in strains limiting phagemid copy number. The reason for this is unclear but it may reflect the strength of the ami promoter causing overexpression to such levels that $E$. coli is killed. The recombinant protein is able to hydrolyse a variety of cell walls, showing most activity on those of $B$. subtilis. No activity was seen using walls of $S$. aureus, perhaps due to $O$ acetylation levels or the different amino acid constituents of the peptidoglycan (Rogers et al., 1980).

An ami mutant was created in the wild-type background to determine the role of the enzyme. Renaturing SDSPAGE revealed that Ami accounts for most of the lytic bands when using L. monocytogenes walls as the substrate. Therefore, it is likely that the $104 \mathrm{kDa}$ proform (as observed on renaturing gels) is exported and then proteolytically processed to give the final profile. This phenomenon has been demonstrated in $S$. aureus, where the major autolysin Atl is post-translationally processed (Foster, 1995). Ami is a major autolysin of L. monocytogenes, as it constitutes $66 \%$ of the total activity when measured using host walls as substrate. As found in other Gram-positive bacteria (Smith et al., 1996) there are, however, likely to be multiple autolysins in L. monocytogenes. Renaturing SDS-PAGE shows that the remaining autolysins in the ami mutant have different substrate specificity than Ami, which may indicate alternative functions.

Although Ami is a major autolysin, its function is not clear. The enzyme appears ostensibly not to be involved in the cell-separation stage of cell division. However, due to the compensatory nature of autolysins, it is only by the creation of multiple autolysin mutants that their combined roles can be determined (Smith \& Foster, 1995; Smith et al., 1996). Both the major amidase (LytC/CwlB) and the major glucosaminidase (LytD) of B. subtilis are involved in cell separation, but this is only apparent when a double mutant is created (Blackman et al., 1998). Ami has a subtle role in motility, observed as a reduction in swarming. This effect on swarming has also been noted for both of the major vegetative-cell autolysins of B. subtilis (Blackman et al., 1998). Even a slight decrease in the ability of the cells to separate will result in an inhibition of swarming, as unseparated cells will be unable to chemotax effectively.

Penicillin-induced lysis occurs as a post-mortem event after the cells have been killed. In $S$. aureus, the major autolysin Atl is responsible for this process. In B. subtilis, LytC is solely responsible for generalized cell lysis but both LytC and LytD are involved in antibiotic-induced lysis (Blackman et al., 1998). However, it appears that wild-type L. monocytogenes is relatively resistant to lysis and seemingly Ami does not have a role in 
penicillin-induced lysis, as neither the mutant nor the control cells lysed completely. Similarly, Ami does not have a role in generalized cell lysis due to Triton X-100.

Autolysins have been implicated as having a role in virulence in several studies. The pneumolysin from Streptococcus pneumoniae is located in the cytoplasm and is thought to be released as the cells undergo autolysis, due to the action of the major autolysin, LytA (Berry et al., 1992). Similarly, the glucosaminidase from $S$. aureus has been shown to strongly depress the immune system in mice and may also interfere with human immune responses (Valisena et al., 1991). L. monocytogenes mutants with reduced p60 levels exhibited reduced (if any) ability to invade host cells (Kuhn \& Goebel, 1989). A mutant of $S$. aureus with reduced autolysin levels exhibited attenuated virulence in experimental models of rat endocarditis (Mani et al., 1994). The ami mutant created in the wild-type background during this study provides the opportunity to determine the role of the enzyme in the invasive properties of the organism.

Even though Ami is a major autolysin of L. monocytogenes, there are still a number of other activities associated with the cell. It is only by the identification of the structural genes encoding the other enzymes and the creation of individual and multiple mutants in an isogenic background that the roles of the many autolysins of $L$. monocytogenes will begin to be elucidated. This forms the focus of our continuing research.

\section{ACKNOWLEDGEMENTS}

We are grateful to W. D. Wuenscher for the provision of $L$. monocytogenes EGD and to C. O'Byrne for pAULA. This work was supported by the BBSRC (A.M.M.) and the Royal Society (S. J.F.). We would also like to thank the BBSRC for the use of the Seqnet computing facilities at Daresbury, UK.

\section{REFERENCES}

Atrih, A., Zollner, P., Allmaier, G. \& Foster, S. J. (1996). Structural analysis of Bacillus subtilis 168 endospore peptidoglycan and its role during differentiation. J Bacteriol 178, 6173-6183.

Berry, A. M., Paton, J. C. \& Hansman, D. (1992). Effect of insertional inactivation of the genes encoding pneumolysin and autolysin on the virulence of Streptococcus pneumoniae type 3. Microb Pathog 12, 87-93.

Blackman, S. A., Smith, T. J. \& Foster, S. J. (1998). The role of autolysins during vegetative growth of Bacillus subtilis 168. Microbiology 144, 73-82.

Braun, L., Dramsi, S., Dehoux, P., Bierne, H., Lindahl, G. \& Cossart, P. (1997). InlB: an invasion protein of Listeria monocytogenes with a novel type of surface association. Mol Microbiol 25, 285-294.

Chakraborty, T., Leimeister-Wăchter, M., Domann, E., Hartl, M., Goebel, W., Nichterlein, T. \& Notermans, S. (1992). Co-ordinate regulation of virulence genes in Listeria monocytogenes requires the product of the prfA gene. J Bacteriol 174, 568-574.

Chu, C.-P., Kariyama, R., Daneo-Moore, L. \& Shockman, G. D. (1992). Cloning and sequence analysis of the muramidase-2 gene from Enterococcus hirae. J Bacteriol 174, 1619-1625.
Dramsi, S., Biswas, I., Maguin, E., Braun, L., Mastroeni, P. \& Cossart, P. (1995). Entry of Listeria monocytogenes into hepatocytes requires expression of InlB, a surface protein of the internalin multigene family. Mol Microbiol 16, 251-261.

Dramsi, S., Dehoux, P., Lebrun, M., Goossens, P. \& Cossart, P. (1997). Identification of four new members of the internalin multigene family in Listeria monocytogenes EGD. Infect Immun 65, 1615-1625.

Farber, J. M. \& Peterkin, P. I. (1991). Listeria monocytogenes, a food borne pathogen. Microbiol Rev 55, 476-511.

Foster, S. J. (1991). Cloning, expression, sequence analysis and biochemical characterization of an autolytic amidase of Bacillus subtilis 168 trpC2. J Gen Microbiol 137, 1987-1998.

Foster, S. J. (1992). Analysis of the autolysins of Bacillus subtilis 168 during vegetative growth and differentiation by using renaturing polyacrylamide gel electrophoresis. J Bacteriol 174, $464-470$.

Foster, S. J. (1993). Molecular analysis of three major wallassociated proteins of Bacillus subtilis 168: evidence for processing of the product of a gene encoding a $258 \mathrm{kDa}$ precursor two-domain ligand-binding protein. Mol Microbiol 8, 299-310.

Foster, S. J. (1995). Molecular characterisation and functional analysis of the major autolysin of Staphylococcus aureus 8325/4. J Bacteriol 177, 5723-5725.

Garcia, J. L., Diaz, E., Romero, A. \& Garcia, P. (1994). Carboxyterminal deletion analysis of the major pneumococcal autolysin. $J$ Bacteriol 176, 4066-4072.

Ghuysen, J.-M., Tipper, D. J. \& Strominger, J. L. (1966). Enzymes that degrade cell walls. Methods Enzymol 8, 685-699.

Holtje, J.-V. (1995). From growth to autolysis: the murein hydrolases in Escherichia coli. Arch Microbiol 164, 243-254.

Kuhn, M. \& Goebel, W. (1989). Identification of an extracellular protein of Listeria monocytogenes possibly involved in intracellular uptake by mammalian cells. Infect Immun 57, 55-61.

Kuroda, A. \& Sekiguchi, J. (1991). Molecular cloning and sequencing of a major Bacillus subtilis autolysin gene. J Bacteriol 173, 7304-7312.

Kuroda, A., Sugimoto, Y., Funahashi, T. \& Sekiguchi, J. (1992). Genetic structure, isolation and characterisation of a Bacillus licheniformis cell wall hydrolase. Mol Gen Genet 234, 129-137.

Li, Z., Clarke, A. J. \& Beveridge, T. J. (1996). A major autolysin of Pseudomonas aeruginosa: subcellular distribution, potential role in cell growth and division, and secretion in surface membrane vesicles. J Bacteriol 178, 2479-2488.

Loessner, M. J., Wendlinger, G. \& Scherer, S. (1995). Heterogeneous endolysins in Listeria monocytogenes bacteriophages: a new class of enzymes and evidence for conserved holin genes within the siphoviral lysis cassettes. Mol Microbiol 16, 1231-1241.

Mclaughlan, A. M. \& Foster, S. J. (1997). Characterisation of the peptidoglycan hydrolases of Listeria monocytogenes EGD. FEMS Microbiol Lett 152, 149-154.

Mani, N., Baddour, L. M., Offutt, D. Q., Vijaranakul, U., Nadakavukaren, M. J. \& Jayaswal, R. K. (1994). Autolysis-defective mutant of Staphylococcus aureus: pathological considerations, genetic mapping and electron microscopic studies. Infect Immun 62, 1406-1409.

Margot, P., Roten, C.-A. H. \& Karamata, D. (1991). NAcetylmuramoyl-L-alanine amidase assay based on specific radioactive labelling of muropeptide L-alanine: quantification of the enzyme activity in the autolysin deficient Bacillus subtilis 168 , flaD strain. Anal Biochem 198, 15-18. 
Oshida, T., Sugai, M., Komatsuzawa, H., Hong, Y.-M., Suginaka, H. \& Tomasz, A. (1995). A Staphylococcus aureus autolysin that has an $N$-acetylmuramoyl- $L$-alanine amidase domain and an endo- $\beta$ - $N$-acetylglucosaminidase domain: cloning, sequence analysis and characterisation. Proc Natl Acad Sci USA 92, 285-289.

Park, S. F. \& Stewart, G. S. A. B. (1990). High-efficiency transformation of Listeria monocytogenes by electroporation of penicillin treated cells. Gene 94, 129-132.

Rogers, H. J., Perkins, H. R. \& Ward, J. B. (1980). Structure of peptidoglycan. In Microbial Cell Walls and Membranes, pp. 190-214. London: Chapman \& Hall.

Romero, A., López, R. \& Garcia, P. (1990). Sequence of the Streptococcus pneumoniae bacteriophage HB-3 amidase reveals high homology with the major host autolysin. J Bacteriol 172, 5064-5070.

Sambrook, J., Fritsch, E. F. \& Maniatis, T. (1989). Molecular Cloning: a Laboratory Manual, 2nd edn. Cold Spring Harbor, NY: Cold Spring Harbor Laboratory.
Smith, T. J. \& Foster, S.J. (1995). Characterisation of the involvement of two compensatory autolysins in mother cell lysis during sporulation of Bacillus subtilis 168. J Bacteriol 177, 3855-3862.

Smith, T. J., Blackman, S. A. \& Foster, S. J. (1996). Peptidoglycan hydrolases of Bacillus subtilis 168. Microb Drug Resist 2, 113-118.

Valisena, S., Varaldo, P. E. \& Satta, G. (1991). Staphylococcal endo- $\beta$ - $N$-acetylglucosaminidase inhibits response of human lymphocytes to mitogens and interferes with production of antibodies in mice. J Clin Invest 87, 1969-1976.

Ward, J. B. \& Williamson, R. (1984). Bacterial autolysins: specificity and function. In Microbial Wall Synthesis and Function, pp. 159-166. Edited by C. Nombela. Amsterdam: Elsevier. Wuenscher, M. D., Köhler, S., Bubert, A., Gerike, U. \& Goebel, W. (1993). The iap gene of Listeria monocytogenes is essential for cell viability, and its gene product $\mathrm{p} 60$, has bacteriolytic activity. J Bacteriol 175, 3491-3501.

Received 12 November 1997; accepted 19 January 1998. 